\title{
Citizens' preferences towards modes of representation: analysis and typology of the Spanish case
}

\author{
http://dx.doi.org/10.15304/rips.18.1.5750 \\ Mikel Barreda \\ UNIVERSITAT OBERTA DE CATALUNYA, BARCELONA, SPAIN \\ mbarreda@uoc.edu \\ Leticia M. Ruiz Rodríguez \\ UNIVERSIDAD COMPLUTENSE DE MADRID, SPAIN \\ leticiamaria.ruiz@cps.ucm.es
}

\begin{abstract}
This article analyses the preferences of Spaniards with regard to the way in which members of Parliament and political parties exercise representation. A homogeneity multivariant analysis (HOMALS) with data from a public opinion survey is used to establish a typology of the public's preferences, related to the distinction between 'top-down' and 'bottom-up' developed by Andeweg and Thomassen (2005). In addition, a logistic regression analysis demonstrates that a range of sociodemographic and political factors affect preferences for representation. In particular, one factor is identified that has been undervalued in the literature to date: the size of the town.
\end{abstract}

Key words: political representation, political preferences, modes of representation, Spain.

Resumen: Este artículo analiza las preferencias de los españoles respecto al modo en que los miembros del parlamento y los partidos políticos ejercen la representación. Para ello se ha realizado un análisis multivariante de homogeneidad (HOMALS) a partir de datos de una encuesta de opinión pública. Este análisis ha permitido establecer una tipología de preferencias ciudadanas, relacionada con la distinción de representación "top-down" y "bottom-up" desarrollada por Andeweg y Thomassen (2005). Asimismo, un análisis de regresión logística evidencia que un conjunto de factores sociodemográficos y políticos afectan a las preferencias sobre representación. En particular, se ha identificado la influencia de un factor que, hasta la fecha, había estado desatendido en la literatura: el tamaño del municipio.

Palabras clave: representación política, preferencias políticas, modos de representación, España.

\section{Introduction}

t $t$ is often said that the general public is dissatisfied with the system of democratic representation. Surveys in numerous countries show a marked distancing between the public and their representatives. For example, the Latinobarómetro 
finds that the percentage of Latin Americans who agree with the opinion 'they govern for the benefit of a few powerful people' rose from 61 per cent in 2009 to 73 per cent in 2016. This climate of opinion has in many cases led to social protest movements directed against the institutions and actors of political representation. The 15M movement in Spain, Occupy Wall Street in the United States and the Indignados movement in Brazil are just a few examples of this activity. All these manifestations of democratic dissatisfaction are not new, as shown by the literature on political trust over a number of decades (Crozier, Huntington and Watanuki, 1975). Since then, expressions such as 'a crisis of democracy', 'ungovernability', 'crisis of representation' and 'loss of trust' have become commonplace in diagnosing democratic societies. However, a new aspect in this phenomenon is the intensity and extent of public discontent with institutions of political representation, due, above all, to the latest global economic crisis (Oñate, 2016) and the growing use of new technologies in the public's collective action (Castells, 2012).

Democratic representation has been one of the priority topics in political science in recent decades. Despite the wealth and variety of approaches to its study, significant questions remain that have received limited attention. One of these is public's concepts of the mode of exercising political representation. Studies on the topic have been largely theoretical and those that provide empirical contributions prioritise the point of view of the political elites (Bengtsson and Wass, 2010). Yet examining citizens' perceptions of representative activity is a relevant approach. As Martínez and Méndez (2002), Carman (2007) and Bengtsson and Wass (2010), among others, suggest, the gap between citizens' perceptions of representation and its reality could affect attitudes and behaviours of discontent and dissatisfaction towards political institutions.

This article analyses the preferences of Spaniards with regard to the form in which members of parliament (MPs) and political parties exercise representation. At least two factors make the Spanish case of particular academic interest. The first relates to the major transformations that have occurred in the representational arena, such as the erosion of support for the two parties that traditionally have the highest percentage of the vote (the Partido Popular [People's Party, or PP] and the Partido Socialista Obrero Español [Spanish Socialist Workers' Party, or PSOE], the irruption of new parties (Ciudadanos [Citizens], VOX, and Podemos [literally, 'We can']), offering new styles of conducting politics (Orriols and Cordero, 2016) and the appearance of a social movement critical of the representation system, which has had major international repercussions (the $15 \mathrm{M}$ movement, as mentioned above), accompanied by a notable drop in public regard for political institutions, especially the parties (Torcal, 2016). Secondly, the experience of a severe economic crisis, which 
started in 2008, and its subsequent management are largely responsible for all these sociopolitical changes (Sánchez-Cuenca, 2014).

Given this situation, examining public perceptions of modes of representation will help better understand the state of representative democracy in Spain and some of its recent changes. The study will attempt to answer two specific questions. The first is, what are the preferences of Spaniards with regard to the mode of political representation? To answer this, a classification of public preferences will be developed using inductive logic. This classification relates to the distinction formulated by Andeweg and Thomassen (2005) between 'top-down' representation (run by the political elites) and 'bottom-up' representation (subordinate to the demands and instructions of the electorate). The second question is what factors explain the public's preferences with regard to the mode of representation? Our view takes into account that this is a phenomenon with multiple causes, although orientation towards the political parties are the main factor, bearing in mind the considerable increase in antipartisan attitudes since the start of the economic crisis (Torcal, 2016). In that context, our hypothesis is that negative attitudes towards parties lead to prefer bottom-up representation, while positive attitudes towards parties increase the preference for top-down representation.

The study is divided into four sections. The first section reviews the literature on modes of representation, paying special attention to the most useful conceptual categories for the empirical study of this topic. In addition, the main explanatory variables for public preferences on the form of exercising representation are examined. Secondly, the data and selected techniques are presented. Thirdly, a typology of preferences with regard to the mode of representation is constructed, based on the various public perceptions. Fourthly, the impact of various sociodemographic and political variables on types of preferences on the form of representation are analysed. Finally, the general conclusions from the study are presented.

\section{Modes of Political Representation}

One of the classic debates in the literature on democracy and political representation concerns modes of representation, i.e. the way in which MPs relate to their voters (Andeweg and Thomassen, 2005). The mandate-independence controversy, which characterises part of the initial reflection on systems of representative government, remains a valid one (Pitkin, 1967). Should representatives follow the instructions or mandates of their electorate? Or, conversely, should representatives feel free to follow their own criteria in seeking the wellbeing of their voters?

With this question as its backdrop, the academic discussion on modes of political representation has developed through normative and empirical approaches. 
Significant among the normative approaches is the construction of typologies of modes of representation, of which three are worth highlighting. The first is the difference between republican and liberal (or pluralist) models of representation (Offe and Preuss, 1990; Rehfeld, 2009). For republicans, the purpose of representation is to achieve the 'general interest' of the community, while for liberals or pluralists the aim of representation is to guarantee the 'private interests' in the community. Pitkin (1967) offers another classification, which distinguishes between two types of representation: descriptive representation, by which the representative is conceived not so much as someone who acts on behalf of others, but someone who 'replaces' them; and substantive representation, which implies that the representative can act freely, in accordance with what he or she considers the voters' best interests. ${ }^{1}$ Finally, Mansbridge $(2003 ; 2011)$ revises the classic mandate versus independence dichotomy and, on the basis of four categories (focus, direction of power, normative criterion and accountability), formulates four models of representation: promissory (provided in election campaigns); anticipatory (linked to the idea of retrospective voting); gyroscopic (based on principles and objectives that guide the representative's actions) and surrogate (when an MP represents voters for districts other than his or her own). ${ }^{2}$

Empirical approaches to the study of modes of representation have been less frequent. Three issues have received the most attention (Weßels, 2007; Bengtsson and Wass, 2010). The first refers to the 'focus' of representation, in other words, who MPs represent in their activity. In the literature, three types of interests that representatives are likely to defend have been identified: territorial interests (such as a whole country or an electoral district); functional interests linked to the interests of certain groups and social sectors; and party interests (Eulau et al., 1959; Brack et al., 2012).

The second issue refers to the 'style' of representation, i.e. the form in which MPs represent their respective principles, in the sense attributed to the theory of agency, and the level of autonomy they enjoy in this respect. One well-known classification is that of Eulau et al. (1959), which identifies three styles of representation: as trustees, delegates and politicos. The figure of trustee is based on Burke's ideal representative (2005: 13): an MP who represents a single interest, not the 'whole' of the country, and who therefore cannot follow anyone's instructions; he can only be guided by 'his unbiased opinion, his mature judgement, his enlightened conscience [...]'. The delegate is a representative who acts through mandate, following the instructions of a

1. Other concepts of representation (representation as authorisation, as responsibility and symbolic) can be found in Pitkin (1967). See also Martínez (2004).

2. In the debate with Mansbridge, Rehfeld (2009) offers a new typology for modes of representation, based on three categories: i) the aims of legislation (republicans versus pluralists); ii) the source of judgement (self-reliant versus the judgement of others); iii) responsiveness (more or less) to the electorate's sanctions. 
principal, who is a 'higher authority' (e.g. the voters). And the politico is a representative who, depending on circumstances, behaves as a delegate or a trustee. As well as this distinction, Eulau et al. also consider the criterion of 'focus', in their study on the roles of legislators. ${ }^{3}$ This typology has recently been the target of criticism. Among other points, attention has been drawn to its ambiguity when applied empirically and its limitations, given that it omits the influence parties exercise on representatives (Andeweg and Thomassen, 2005). This omission is particularly relevant in European parliamentary systems: given the highly centralised, disciplined and hierarchical parties, most MPs tend to act as party delegates, rather than delegates of the voters or trustees (Oñate, 2016). Given these deficiencies, Andeweg and Thomassen (2005) construct a new classification based on two criteria: the direction of representation (bottom-up, citizens, and top-down, the representatives) and the type of political control ('ex ante' or 'ex post', in relation to the act of representation). On this basis, four forms of representation are identified: authorisation, delegation, accountability and responsiveness.

Finally, the third issue in empirical studies on modes of representation is the congruence between MPs' and voters' preferences. Some authors maintain that representation based on the 'government by the responsible party' model is the one that best ensures this match. According to this model, during elections the parties present different policies that they would implement when in government and which orient the public's votes (Adams, 2001). Other authors, however, indicate that this model provides an idealised and unreal vision of representative government, above all with regard to fulfilling electoral promises (Brack et al., 2012).

\section{Citizens' Perceptions of the Modes of Political Representation}

The empirical studies on representation are lacking in research into public perceptions on the mode in which representation is conducted. The focus is more on analysing MPs' visions of their own roles of representation (e.g. Converse and Pierce, 1979; Andeweg and Thomassen, 2005; Esaiasson, 2000; Brack et al., 2012) and the congruence between representatives and the electorate (e.g. Miller and Stokes, 1963; Erikson, 1978; Herrera et al., 1992). This has led to a lack of data and knowledge on citizens' perceptions and preferences with regard to representation.

To date, studies on citizens' perceptions of modes of parliamentary representation follow two directions. The first analyses these perceptions by focussing on the public's preferences with regard to styles of parliamentary representation. The results vary

3. Although Eulau et al. (1959) note that the question of focus refers to different types of functional and territorial interests prioritised by MPs, their empirical study is limited to the interests of territorial representation. 
from country to country. Thus, while the work by Bengtsson and Wass (2010) shows a clear preference among Finnish voters for an independent style of representation, Davidson (1970) finds that the North American public prefers the delegate style. Over and above differences between countries, it is worth bearing in mind the diversity of conceptual frameworks and methodologies used, which make comparison difficult.

The second direction of study on public perceptions of modes of representation is the analysis of determining factors in these perceptions. The literature discusses the influence of a diversity of individual variables relating to sociodemographic and political characteristics. In relation to sociodemographic variables, the studies by Carman $(2006 ; 2007)$ show that people with higher educational and social levels tend to prefer a more independent (or trustee) style of representation, while women and young people tend to prefer close, direct links with representatives. With regard to political variables, Bengtsson and Wass (2010) classify them into two groups. Firstly, there are those that measure the 'level of political sophistication': political interest and knowledge. According to this classification, the higher the level of political sophistication, the greater the preference for an independent style of representation. Secondly, there are a set of variables that measure individual integration in political systems. These include the action of voting, political efficacy, trust in government and party identification. The most widespread view is that satisfaction with how the political system works favours a preference for an independent mode of representation. However, empirical evidence is inconclusive. The studies by Carman $(2006 ; 2007)$ support this thesis, as they show that political efficacy, trust in government and party support contribute positively to a preference for the trustee option. However the findings of Bengtsson and Wass (2010) point in the opposite direction: a positive view of the responsiveness of the political system and party identification favour a preference for representatives who act as voters' delegates.

These latter authors include another variable in this group of political integration: position on the left-right axis. They find that the positioning on the right favours a preference for an independent form of representation, while positioning on the left favours a preference for the delegate representation model.

Research analysing modes of political representation based on surveys among MPs confirms the incidence of a wider and more varied number of factors. As well as the influence of MP-related variables, such as level of political experience or responsibilities in the party, the influence of party-related variables, such as level of centralisation and professionalism, and the institutional system, such as electoral rules (Brack et al., 2012) has also been identified.

Some recent studies analyse the political effects of preferences on modes of representation. Specifically, Barker and Carman (2010) confirm the influence of these preferences in the voting decisions of Americans. Citizens who prefer a 'conscience-based' type of representation (the trustee) tend to vote for Republican 
Party candidates in both primary and presidential elections, while those who prefer a 'constituents-based' representation (delegate) tend to vote for Democrat candidates. Thus, preferences with regard to modes of representation appear as a predictor of vote.

In the case of Spain, recent research compares the public and MPs' opinions on the form of exercising representation. ${ }^{4}$ The research reveals the theoretical and methodological diversity mentioned above. These studies use different conceptual references and classifications of modes of representation, such as those formulated by Eulau et al. (in the studies by Méndez and Martínez, 2002; Méndez, 2006), Andeweg and Thomassen (Oñate, 2016) and Rehfeld (Mota, 2016). Similarly, different questions and data sources are used, leading to a wide disparity in results. For instance, according to Coller, Jaime and Mota (2016) and Mota (2016), most Spaniards prefer a representative who operates as a delegate of the public. However, the study by Oñate (2016), based on surveys in four Spanish autonomous communities, indicates that most people prefer a representative who acts as a trustee. In this context, the present article intends to contribute in two ways. Firstly, it aims to provide a new measurement and classification for public preferences on modes of representation. Secondly, it approaches the explanatory dimension of such preferences, an issue that has received little attention in studies of the Spanish case.

\section{Methodology: Data and Techniques}

The analysis of citizens' perceptions regarding the form in which MPs and parties articulate political representation in Spain uses data on public opinion from the Centro de Investigaciones Sociológicas (Centre for Sociological Research, CIS) study 2930, Congruencia ideológica entre electores y representantes políticos (2012). This study contains a large number of questions on political representation. The survey was conducted after the start of the 2007-08 financial crisis and numerous corruption scandals that have come to light involving the Spanish political class. Thus the response map provides a valid, up-to-date picture. In addition, this survey from 2012, which remains the most recent approach to public preferences regarding political representation in Spain at the national level, was designed mainly to capture Spaniards' preferences on structural features of their political culture. That is another of the reasons to believe on its ability to capture current attitudes towards political representation.

Two of the questions in the CIS survey examine preferences on the types of interests MPs should prioritise in their representation, i.e. the 'focus' of their

4. The main references are the studies by Méndez and Martínez (2002), Méndez (2006), Oñate (2016), Coller, Jaime and Mota (2016), and Mota (2016). To these studies should be added others that analyse political disaffection and capture the decline in trust in actors and institutions of representation (such as Torcal, 2014, 2016). 
representation. Specifically, one question measures which interests MPs should favour in conflicts of interests between the party and constituents. The other question asks the citizen to choose between representatives who reach agreements while occasionally setting aside their own or their party's ideology, or representatives who are loyal to these positions even if this means failing to reach agreements. The survey also includes a question based on the typology by Eulau et al. (1959) on 'styles' of representation: MPs should follow their own criteria (trustees), they should bear in mind the opinions of their electorate (delegates) or they should follow one or other criterion depending on the circumstances (politicos).

Along with the descriptive analysis of these three questions on the focus and style of representation, three further techniques are used. Firstly, a homogeneity multivariant analysis (HOMALS) is applied to the categories of questions on 'focus' and 'style' of political representation. In addition, the main explanatory variables for citizens' preferences on the form of exercising representation are examined. This is supplemented by a k-mean clustering analysis applied to the factorial scores obtained from the HOMALS analysis, in order to establish the distribution of individuals in the groups observed in the homogeneity analysis. The main advantage of this cluster analysis is to permit the establishment of homogeneous groups so that members of the public belonging to the same group are similar, i.e. the values taken in each of the variables in the analysis are analogous. Finally, a logistic regression analysis is conducted to identify the factors that best explain the types of public preferences established by the previous analyses. The resulting model includes explanatory variables highlighted in the literature on modes of representation.

\section{Citizen Typology Based on their Preferences for Modes of Representation}

As previously stated, there are few studies and data available on public perceptions and preferences with regard to the form of exercising political representation in Spain. This study presents a typology of Spaniards based on their preferences for how they think they should be represented by MPs, using the most recent empirical evidence on representatives nationwide. A new analytical approach is used here, compared to previous studies: the typology is not developed from a theoreticalconceptual framework, but from inductive logic based on a HOMALS analysis, with data from CIS study 2930 (2012). HOMALS is one of a group of exploratory nonlinear multivariate analysis techniques that works with nominal variables and is calculated using alternating least squares (Gifi 1990). The aim of this factorial interdependence technique is to identify a small space to summarise and represent the structures of associations between two or more nominal variables and similarities between the subjects belonging to these categories. In particular, perceptions with 
regard to three variables are examined. Two of them concern the question of the focus of representation: priority between party and territorial interests and loyalty to ideological or party positions. The third variable refers to the style of representation and, in particular, the typology by Eulau et al. (1959).

Table 1 shows the answers to these three questions. With regard to the focus of representation, the preference for a type of representation centred on party interests has little support. Thus, firstly, most members of the public state that, given a situation of conflict of interests between the party and the MPs' constituents, territorial interests should take priority (56.5 per cent). Secondly, a majority also agree with the option of having representatives who are capable of reaching agreements, although this might mean setting aside their own or their party's ideological positions (69 per cent). With regard to the three alternative styles of representation, one is clearly favourite: the preference for an MP who operates as a delegate for his or her voters (75 per cent). If attitudes on focus and style of representation are considered jointly, a general conclusion may be drawn: most members of the public prefer a bottom-up mode of representation, in the sense of Andeweg and Thomassen (2005), i.e. the model of MP at the service of the interests and demands of the public.

Table 1

Preferences on focus and style of representation from the 2012 survey (\%)

\begin{tabular}{|c|c|}
\hline \multicolumn{2}{|c|}{$\begin{array}{l}\text { Priority between party and territorial interests } \\
\text { In case of contradiction between interests of the party and the province or autonomous community, MPs should: }\end{array}$} \\
\hline Give priority to the province or autonomous community & 56.5 \\
\hline Follow party lines & 8.4 \\
\hline Try to moderate the party position & 25.9 \\
\hline N/A & 9.2 \\
\hline \multicolumn{2}{|l|}{ Loyalty to ideological or party positions } \\
\hline $\begin{array}{l}\text { The important thing is for politicians to reach agreements and negotiate solutions, even if they } \\
\text { sometimes have to put their own or their party's ideological positions to one side. }\end{array}$ & 69 \\
\hline $\begin{array}{l}\text { The important thing is for politicians to be true to their or their party's ideological positions, even } \\
\text { if this sometimes means failing to reach an agreement or negotiate solutions. }\end{array}$ & 16.4 \\
\hline Depending on the subject of the agreement or negotiation (DO NOT READ) & 8.2 \\
\hline \multicolumn{2}{|l|}{ Styles of representation } \\
\hline Representatives should follow their own criteria & 11.9 \\
\hline Representatives should take into account the opinions of the electorate & 75 \\
\hline It depends on the issue & 7.3 \\
\hline N/A & 5.8 \\
\hline$(\mathrm{N})$ & 2478 \\
\hline
\end{tabular}

Source: the authors. Data from CIS Es2930. 
A homogeneity analysis was conducted on the three nominal variables. The results show that the percentage fit of the model is very high (90 per cent), with eigenvalues of 0.47 for axis 1 and 0.43 for axis 2 . The three variables contribute to identifying the response categories on the graph axes, but in a different manner (Table 2). The style of representation and loyalty to ideological or party positions variables largely define the position on axis 1 , while the variable priority between party and territorial interests defines the position on axis 2 to a greater extent.

Table 2

Discrimination measures in the homogeneity analysis using the 2012 survey

\begin{tabular}{|l|c|c|}
\hline \multicolumn{1}{|c|}{ Variables } & \multicolumn{2}{|c|}{ Dimension } \\
\cline { 2 - 3 } & 1 & 2 \\
\hline Styles of representation & & \\
- Representatives should follow their own criteria & & \\
- Representatives should take into account the opinions of the electorate & 0.755 & 0.402 \\
- It depends on the issue & & \\
\hline $\begin{array}{l}\text { Priority between party and territorial interests } \\
\text { In case of contradiction between interests of the party and the province or autonomous } \\
\text { community, MPs should: }\end{array}$ & & \\
- Give priority to the province or autonomous community & & \\
- Follow party lines & & \\
- Try to moderate the party position & 0.041 & 0.471 \\
\hline $\begin{array}{l}\text { Loyalty to ideological or party positions } \\
\text { - The important thing is for politicians to reach agreements } \\
\text { - The important thing is for politicians not to renounce their or their party's ideological } \\
\text { positions }\end{array}$ & & \\
- It depends on the issue & & \\
\hline
\end{tabular}

Source: Results of the homogeneity multivariate analysis with data from CIS Es2930.

Graph 1 represents the distribution of categories of variables with regard to the two axes. ${ }^{5}$ Three groups of categories were detected. The first group, at the bottom

5. The category quantifications represent the mean scores of the objects in the same category. 
of the graph, includes: the opinion that political representatives should exclusively follow their own criteria when making political decisions, even if this does not coincide with that of their electorate; the view that, in the event of a contradiction between party and provincial or autonomous community interests, the MP should follow party directives; and the preference for MPs being faithful to their own or their party's ideological positions. These opinions express a preference for a top-down model of representation, which focuses on political elites in the representation process.

The second group of categories (top-left quadrant) brings together three opinions: representatives should take into account their electorate's opinions when making decisions, even though they do not match their own; in the conflict of interest between party and province or autonomous community, MPs should give priority to their province or try to moderate their party's position on the topic; and the importance of politicians reaching agreements and negotiating solutions, although this means compromising some of their or their party's ideological positions. Thus, unlike the previous group, this one shows a preference for bottom-up representation, which prioritises the interests of the public and the territory over the interests of political elites.

The last group (top-right quadrant) includes the answers for it depends on the topic with regard to the two alternatives: prioritising party interests over those of the electorate; and reaching agreements between politicians as opposed to remaining faithful to individual or party ideological positions. Therefore, it does not include precise, defined preferences for top-down or bottom-up representation, but considers the choice of one or the other to depend on the topic of decision or negotiation among political representatives.

To supplement this, a k-mean clustering analysis applied to the factorial scores obtained from the HOMALS analysis was conducted in order to establish the distribution of individuals in the three groups. Graph 2 gives information on these groups, particularly with regard to their composition and the weight of the responses from individuals in each group. Thus cluster 2 is the most numerous (1486) and the most homogeneous: 100 per cent of its members consider that representation should take into account the opinion of the electorates and that the important thing is for representatives to reach agreements, although this means waiving some of their own or their party's ideological principles; in addition, most of the them (68.9 per cent) place the interests of territorial representation over party. Thus, this is a group that favours a bottom-up representation model. 


\section{Graph 1}

Quantifications of categories using the 2012 survey

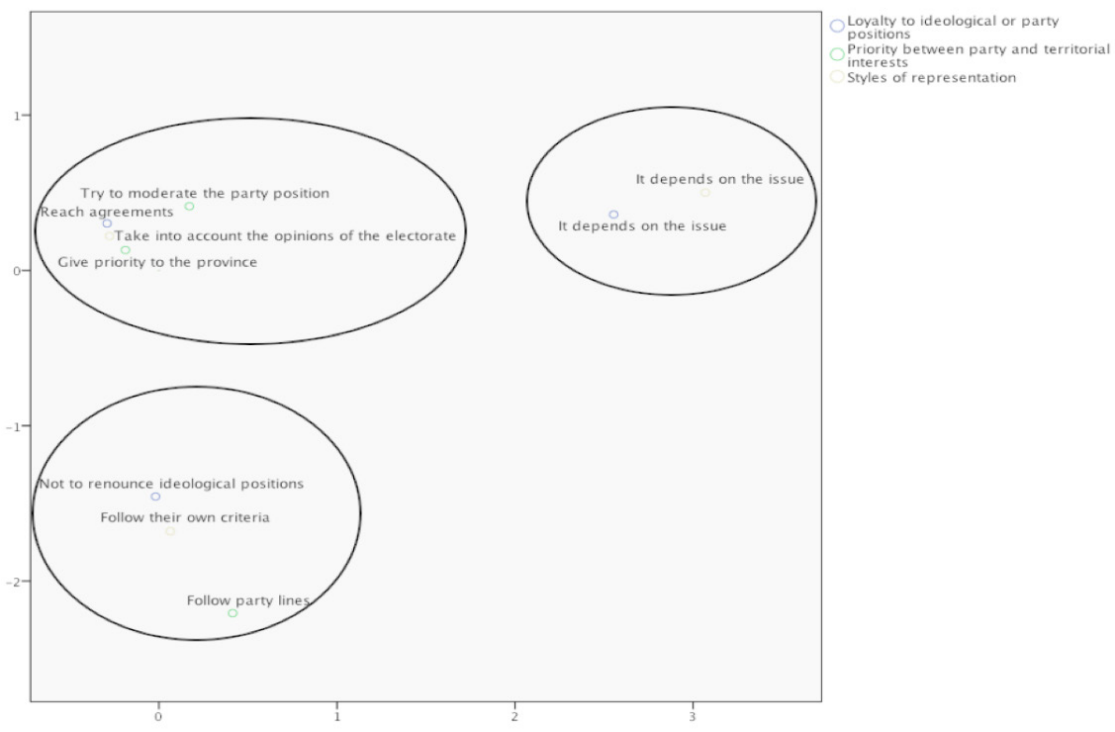

Source: the authors. Data from CIS Es2930.

The size of cluster 1 is approximately half that of the previous cluster (677) and includes those citizens with divided opinions on the modes of representation. In this group, although preferences for a bottom-up type of representation are the majority view, preferences for top-down representation are more widespread. Thus 41.6 per cent of group members think that representatives should follow exclusively their own criteria when making political decisions and 58.9 per cent express a preference for MPs who are loyal to their or their party's ideological positions.

Finally, cluster 3 is the smallest (315) and has the least internal cohesion. It is made up of those citizens who do not show a clear preference for top-down or bottom-up political representation, but see it as dependent on the topic on which the representative has to decide. Thus, this is a preference for a mixed type of representation. Note that the options of 'it depends' with regard to the style of representation and loyalty to ideological or party positions are shared by more than 50 per cent of this group. Another opinion that shows an intermediate or moderate position to opposing points of view relates to the focus of representation: 34.3 per cent think that MPs should moderate the party position in cases of contradiction between territorial and party interests. 


\section{Graph 2}

Weight of main responses from individuals in each cluster in the 2012 survey

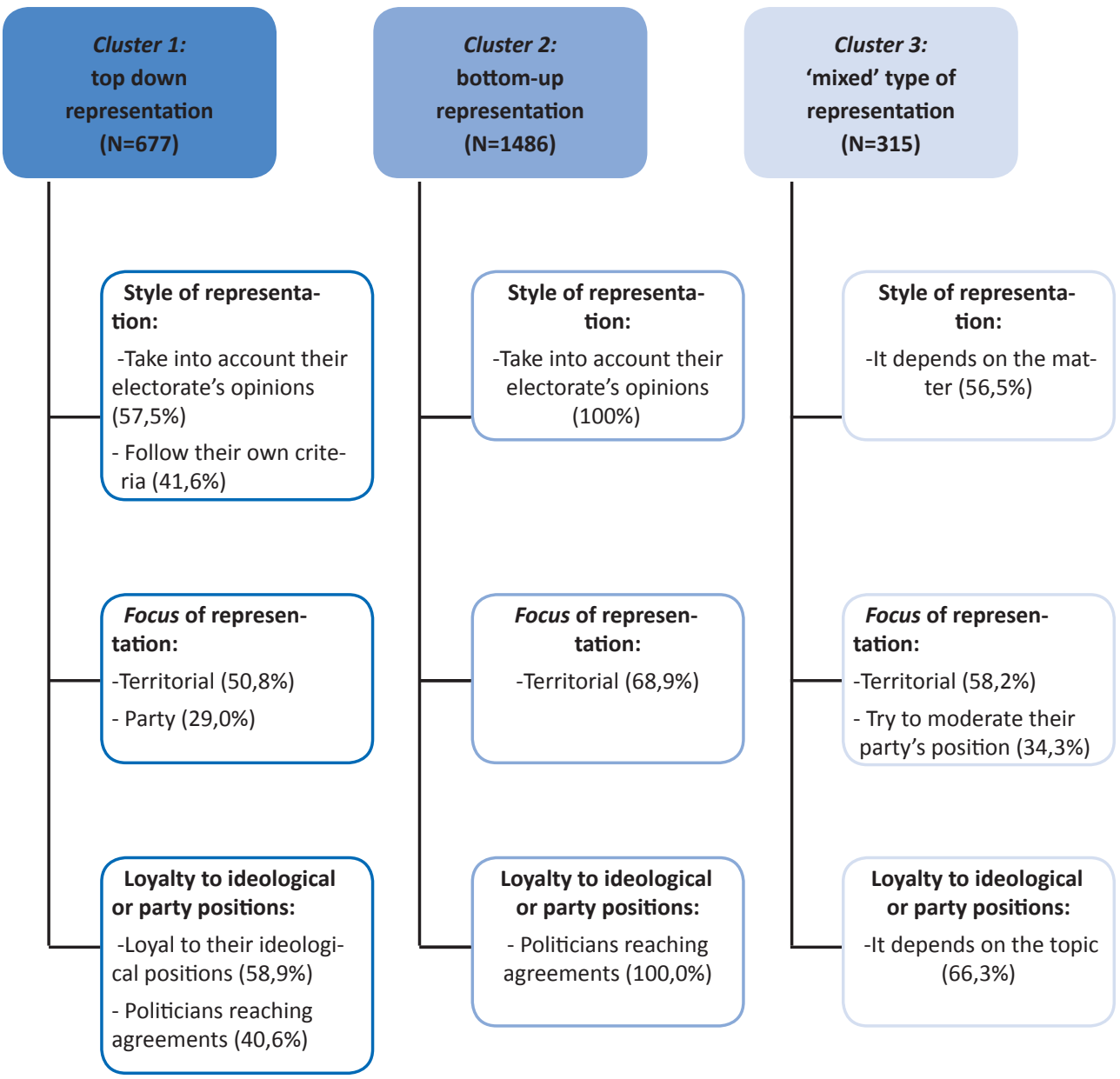

Source: the authors. Data from CIS Es2930.

\section{Determining Factors for Preferences on Modes of Representation}

As already seen, the typology of public preferences on modes of representation arising from the previous analysis is similar to the classification by Andeweg and Thomassen (2005). This section examines factors affecting these preferences. For greater simplicity, the explanatory analysis is limited to types of preference that clearly 
mark the direction of representation: top-down or bottom-up. ${ }^{6}$ These two categories thus represent the dependent variable in our study. To measure them, the value of 0 was assigned to the group with a greater preference for top-down (cluster 1), while the value 1 was assigned to those who favoured bottom-up representation (cluster 2 ).

The selection of independent variables is based on the evidence and conclusions of the research presented above. In total, the influence of 11 variables is examined: five are sociodemographic, two are related to political sophistication, and four to integration in the political system. Table 3 specifies these variables, their indicators and assigned values and the expected relationships of influence on the dependent variable. An additional variable has been added to those presented above: the size of the town. This is an explanatory factor for many political phenomena, yet it is virtually absent from the literature on modes of representation. The only territorial element stressed to date is the size of the electoral district. According to a number of studies, single-member districts are an incentive for a representative of loyalty to constituents rather than the party (e.g. Cox, 2004; Carroll and Shugart, 2007). If one transfers this argument to the size of the town, it might be expected that small towns would prefer MPs whose representation is more bottom-up.

Table 3

Independent variables in the model

\begin{tabular}{|c|c|c|}
\hline Variables & Indicators and values & Expected influence on the dependent variable \\
\hline \multicolumn{3}{|l|}{ Sociodemographic } \\
\hline Sex & Woman (1); man (0) & $\begin{array}{l}\text { Greater preference for top-down representation } \\
\text { among men. }\end{array}$ \\
\hline Age & & $\begin{array}{l}\text { Greater preference for top-down representation as } \\
\text { individuals get older. }\end{array}$ \\
\hline Size of town & $\begin{array}{l}\text { Towns under 10,000 (1); } \\
\text { rest (0) }\end{array}$ & $\begin{array}{l}\text { Greater preference for bottom-up representation in } \\
\text { small towns. }\end{array}$ \\
\hline Education & Primary (1); rest (0) & $\begin{array}{l}\text { The higher the level of education, the greater the } \\
\text { preference for top-down representation. }\end{array}$ \\
\hline Socioeconomic status & $\begin{array}{l}\text { Working class ( } 1 \text { ); middle } \\
\text { and upper class }(0)\end{array}$ & $\begin{array}{l}\text { Greater preference for bottom-up representation in } \\
\text { lower socioeconomic levels. }\end{array}$ \\
\hline
\end{tabular}

6. As noted above, the mixed category does not include precise orientations on how the representative should act, but instead considers this dependent on the nature of the topics of representation. Nor does the descriptive analyses take into account any individual variables significantly associated with this category. 


\begin{tabular}{|c|c|c|}
\hline Variables & Indicators and values & Expected influence on the dependent variable \\
\hline \multicolumn{3}{|l|}{ Political sophistication } \\
\hline Interest in politics & $\begin{array}{l}\text { Scale of one (a lot) to five } \\
\text { (none) }\end{array}$ & $\begin{array}{l}\text { The greater the political interest, the greater the } \\
\text { preference for top-down representation. }\end{array}$ \\
\hline Political information & $\begin{array}{l}\text { Following political news on } \\
\text { the radio or TV (scale of one } \\
\text { (every day) to five (never)) }\end{array}$ & $\begin{array}{l}\text { The greater the political knowledge, the greater the } \\
\text { preference for top-down representation. }\end{array}$ \\
\hline \multicolumn{3}{|c|}{ Integration in the political system } \\
\hline $\begin{array}{l}\text { Assessment of } \\
\text { politicians }\end{array}$ & $\begin{array}{l}\text { Scale of } 0 \text { (very bad) to ten } \\
\text { (very good) }\end{array}$ & $\begin{array}{l}\text { The more favourable the assessment of politicians, the } \\
\text { greater the preference for top-down representation. }\end{array}$ \\
\hline $\begin{array}{l}\text { Assessment of political } \\
\text { parties }\end{array}$ & $\begin{array}{l}\text { Political parties carry out } \\
\text { their manifesto promises } \\
\text { (scale of one (completely } \\
\text { agree) to five (completely } \\
\text { disagree)) }\end{array}$ & $\begin{array}{l}\text { The more favourable the assessment of parties, the } \\
\text { greater the preference for top-down representation. }\end{array}$ \\
\hline Voting & $\begin{array}{l}\text { Voters in the } 2011 \text { general } \\
\text { elections (1); non-voters (0). }\end{array}$ & $\begin{array}{l}\text { Greater preference for top-down representation } \\
\text { among those who voted. }\end{array}$ \\
\hline Ideology & $\begin{array}{l}\text { Position on the left-right axis } \\
(1-10)\end{array}$ & $\begin{array}{l}\text { Right-wing positions show a greater preference for } \\
\text { top-down representation. }\end{array}$ \\
\hline
\end{tabular}

Source: the authors. Data from CIS Es2930.

The results of the logistic regression are shown in Table 4 . The general performance of the model is satisfactory. Three of the commonly used indicators for measuring goodness of fit (omnibus tests, Hosmer test and overall correct classification rate) show an adequate fit. However, the variance in the dependent variable explained by the model is limited (see Nagelkerke's R2), indicating the absence of explanatory factors with a notable weight, which are not included in the survey we used. Indeed, a similar situation, including lower R2s, can be seen in other studies on citizens' understanding of modes of representation (Carman, 2006; Bengtsson and Wass, 2010). In the field of political psychology, there are a number of clues to new explanatory variables that might be considered. We refer here to different situational and dispositional factors (e.g. personality type or traumatic experiences, such as 9/11) which largely determine the public's political attitudes (Thorisdottir, Jost and Kay, 2009; Jost, 2006). Sadly, available surveys rarely consider such information. 
Table 4

Determinants of public preferences for top-down (0) or bottom-up (1) modes of representation using a linear regression analysis

\begin{tabular}{|c|c|}
\hline Sex (men) & $\begin{array}{l}0.247^{*} \\
(0.111)\end{array}$ \\
\hline Age & $\begin{array}{l}0.008 * \\
(0.004)\end{array}$ \\
\hline Size of town (small) & $\begin{array}{c}0.557 * * \\
(0.148)\end{array}$ \\
\hline Education (primary) & $\begin{array}{l}-0.230 \\
(0.130)\end{array}$ \\
\hline Socioeconomic status (workers) & $\begin{array}{c}0.132 \\
(0.122)\end{array}$ \\
\hline Interest in politics & $\begin{array}{c}0.033 \\
(0.045)\end{array}$ \\
\hline Political information & $\begin{array}{c}0.055 \\
(0.041)\end{array}$ \\
\hline Assessment of politicians & $\begin{array}{l}0.046 * \\
(0.023)\end{array}$ \\
\hline Assessment of political parties & $\begin{array}{c}0.258 * * \\
(0.059)\end{array}$ \\
\hline Voting & $\begin{array}{c}-0.369 * \\
(0.169)\end{array}$ \\
\hline Ideology & $\begin{array}{c}-0.083 * * \\
(0.029)\end{array}$ \\
\hline Constant & $\begin{array}{l}-0.528 \\
(0.406)\end{array}$ \\
\hline $\mathrm{N}$ & 1583 \\
\hline Omnibus tests & Chi2: $61.4(0.000 \mathrm{r})$ \\
\hline Hosmer and Lemeshow test & Chi2: $7.701(0.463 r)$ \\
\hline Nagelkerke's R2 & 0.053 \\
\hline$\%$ cases predicted & 67.2 \\
\hline
\end{tabular}

* and ** indicate 90 and 95 per cent significance levels, respectively. The variables of sex, town size, education and status are dichotomous: the category in brackets is the reference (value 1). The values in the table correspond to the logistic regression without standardisation, with the typical errors in brackets.

Source: the authors. Data from CIS Es2930. 
Despite these limitations, the logistic analysis identifies relevant explanatory relations. Of the 11 variables in the model, seven are statistically significant. Conversely, the two political sophistication variables (political interest and information) and two of the sociodemographic variables (education and status), do not have a significant explanatory capacity. In line with this hypothesis, it has been shown that citizens' preferences for modes of representation have multiple causes. However, one aspect of the hypothesis is not confirmed: although opinions on political parties play a key role, they are not the principal explanatory factor. Their place is occupied by the size of the town. As mentioned above, this variable has not previously been considered in studies on the public's concept of representation.

The direction of causal relationships generally fits expectations. In the case of sociodemographic variables, the condition of being a woman, young and living in a small town (under 10,000 inhabitants) favours a preference for bottom-up representation. With regard to political integration variables, the favourable rating of political parties, the vote and holding right-wing positions influence a greater preference for top-down representation. The only case in which a relationship other than expected has been noted is in the assessment of politicians. As can be seen, positive opinions on politicians favour a preference for a bottom-up form of representation.

\section{Conclusions}

The work of parties and politicians has come increasingly into question in Spain in recent years. New cases of corruption and deteriorating economic and social conditions have generated much reflection on representation, among other things. With the aim of updating empirical knowledge of this process, this study analyses the preferences of Spaniards with regard to the form in which MPs and political parties exercise representation. There are three main findings from our study.

Firstly, the data show that a majority of citizens identify with bottom-up representation, where the MP is at the service of the public's interests and demands. By contrast, there is less preference for top-down representation, which gives greater powers and autonomy to representatives over voters. In addition, control of representation by the parties is less popular than the preference for MPs making decisions based on their own judgement. This is related to widespread attitudes of mistrust and hostility to parties, especially since 2008, with the onset of the last great economic crisis.

Secondly, the typology of members of the public based on their preferences in political representation, produced by a HOMALS analysis, identifies three groups. The most numerous and homogeneous group shows a preference for bottom-up 
representation, i.e. prioritising the defence of the public's and the territory's interests over the interests of the political elites. Another group includes members of the public with more divided opinions, in which preferences for top-down representation, giving the political elites (parties and representatives) a greater role in the representation process, are more widespread. The final group is made up of people who favour a mixed model, depending on the topic on which the representative has to decide.

Thirdly, the logistic regression analysis shows the multicausal nature of citizens' preferences on modes of representation. In a context where discontent with parties predominates, we thought that the main explanatory variable for the above preferences would be assessment of parties. However, although this variable plays a relevant role, the best explanatory variable is the size of the town. This is a notable contribution, bearing in mind that this factor is absent from studies on the public's concept of representation. Furthermore, our study shows the significance of three sociodemographic variables (sex, age and size of town) and a further three relating to integration in the political system (assessment of politicians, voting and leftright ideology). In general, the explanatory relationships match expectations. The model explains a small part of the variance in the dependent variable but is useful for showing significant relationships. However, variables on other causal strata which are not usually considered in studies on the public's concept of representation could also be included. Recent research into political psychology suggests other variables (such as political personality) that could be considered (Thorisdottir, Jost and Kay, 2009; Jost, 2006).

These latter reflections show that the conclusions from this study are not definitive. Our aim is to provide a basis for designing future studies on public preferences with regard to representation, incorporating other factors that are not usually considered in opinion polls.

\section{References}

Adams, James (2010) Party Competition and Responsible Party Government. Ann Arbor: Michigan University Press.

Andeweg, Rudy B. and jacques A. Thomassen (2005) "Modes of Political Representation: Toward a New Typology”, Legislative Studies Quarterly, 30 (4), 507-528. https://doi.org/10.3162/036298005x201653

Barker, David and Christopher J. CarmaN (2010) "Yes WE Can or Yes HE Can? Citizen Preferences Regarding Styles of Representation and Presidential Voting Behavior", Presidential Studies Quaterly, 40 (3), 431-448. https://doi.org/10.1111/ j.1741-5705.2010.03779.x 
Bengtsson, Assa and Hanna Wass (2010) "Styles of Political Representation: What Do Voters Expect?", Journal of Elections, Public Opinion and Parties, 20 (1), 55-81. https://doi.org/10.1080/17457280903450724

Brack, Nathalie, Olivier Costa and Conceiçao Pequito (2012) "Attitudes towards the focus and style of political representation among Belgian, French and Portuguese Parliamentarians", Representation, 48(4), 387-402. https://doi.org/10.1080/0034 4893.2012.720884

Burke, Edmund (1774) "Speech to the Electors of Bristol" In Edmund Burke, Miscellaneous Writings. The OnlineLibraryofLiberty, Available online athttp://fs2. american.edu/dfagel/www/Philosophers/Burke/SpeechToTheElectorsofBristol. pdf

Carman, Christopher (2006) "Public preferences for parliamentary representation in the US: an overlooked link?", Political Studies, 54(1), 103-122. https://doi. org/10.1111/j.1467-9248.2006.00568.x

Carman, Christopher (2007) "Assessing preferences for political representation in the US”, Journal of Elections, Public Opinions and Parties, 17(1), 1-19. https://doi. org/10.1080/13689880601132497

Carroll, Royce and Shugart, Matthew (2007) "Neo-Madisonian Theory and Latin American Institutions", in G. MUNCK (ed.) Regimes and Democracy in Latin America, Oxford: Oxford University Press.

Castells, Manuel (2012) Networks of outrage and hope: Social movements in the Internet age, Cambridge: Polity Press.

Coller, Xavier, ANTONIO M. Jaime and Fabiola MOTA (eds.) (2016) El poder político en España: parlamentarios y ciudadanía, Madrid: Centro de Investigaciones Sociológicas.

Cox, Gary (2004) La coordinación estratégica de los sistemas electorales del mundo: hacer que los votos cuenten, Barcelona: Gedisa.

Davidson, RichardH. (1979) "Public prescriptions for thejob of congressman", Midwest Journal of Political Science, 14 (4), 648-666. https://doi.org/10.2307/2110357

Eulau, Heinz. (etal) (1959) "The role of the representative: some empirical observations on the theory of Edmund Burke", American Political Science Review, 53 (3), 742 756. https://doi.org/10.2307/1951941

Erikson, Robert S. (1978) "Constituency opinion and congressional behvior. A reexamination of the Miller-Stokes representation data", American Journal of Political Science, 22 (3), 511-535. https://doi.org/10.2307/2110459

Esaiasson, Peter (2000) "How members of parliament define their task", in P. ESAIASSON and K. HEIDAR (eds.) Beyond Westminster and Congress: The Nordic Experience, Ohio: State University Press. 
Fiorina, Morris P. (1981) Retrospective Voting in American National Elections, New Haven: Yale University Press.

Gifi, Albert (1990) Nonlinear Multivariate Analysis, New York: John Wiley \& Sons.

Herrera, Cheryl L, Richard Herrera and Eric R. Smith (1992) "Public opinion and congressional representation”, Public Opinion Quaterly, 56 (2), 185-205. https:// doi.org/10.1086/269310

Jost, John (2006) “The End of the End of Ideologies", American Psycologist, 6 (7), 61-670.

Mansbridge, Jane (2003) "Rethinking Representation", American Political Science Review, 97(4), 515- 528.

Mansbridge, Jane (2011) “Clarifying the Concept of Representation”, American Political Science Review, 15 (3), 621-630. https://doi.org/10.1017/s0003055411000189

Martínez, Antonia (2004) "La representación política y la calidad de la democracia", Revista Mexicana de Sociología, 66 (4),661-710. https://doi.org/10.2307/3541413

Méndez-Lago, Mónica (2006) "La representación política en España: percepciones de diputados y ciudadanos", in MARTÍNEZ A (ed.) Representación y calidad de la democracia en España, Madrid: Tecnos.

Méndez-Lago, Mónica and Antonia Martínez (2002) "Political representation in Spain: an empirical analysis of the perception of citizens and MPs", Journal of Legislative Studies, 8 (1), 63-90. https://doi.org/10.1080/714003903

Miller, E Warren and Donald E. Stokes (1963) "Constituency influence in congress", American Political Science Review, 57 (1), 45-56. https://doi.org/10.2307/1952717 Mota, Fabiola (2016) "La representación política parlamentaria", in X. COLLER, J. ANTONIO and F. MOTA (eds.) El poder político en España: parlamentarios y ciudadanía, Madrid: Centro de Investigaciones Sociológicas.

Offe, Claus and Ulrich Preuss (1990) "Instituciones democráticas y recursos morales", Isegoría, 2, 45-74. https://doi.org/10.3989/isegoria.1990.i2.390

Oñate, Pablo (2016) "La representación política en España: las perspectivas de los ciudadanos y de los diputados", in F. LLERA (ed.) Desafección política y regeneración democrática: diagnósticos y propuestas, Madrid: Centro de Estudios Políticos y Constitucionales.

Orriols, Lluis and Guillermo CORDERO (2016) "The Breakdown of the Spanish TwoParty System: The Upsurge of Podemos and Ciudadanos in the 2015 General Election", South European Society and Politics, 21 (4), 469-492. https://doi.org/1 $0.1080 / 13608746.2016 .1198454$

Pitkin, Hanna F. (1967) The concept of representation, Los Ángeles: University of California Press, Berkeley. 
Rehfeld, Andrew (2009) "Representation Rethought: On Trustees, Delegates, and Gyroscopes in the Study of Political Representation and Democracy", American Political Science Review, 103 (2), 214-230. https://doi.org/10.1017/ s0003055409090261

Sánchez Cuenca, Ignacio (2014) La impotencia democrática. Sobre la crisis política de España, Madrid: Libros de la Catarata.

Thorisdottir, Hulda, Jost, John and Kay, Aaron (2009) "On the Social and Psychological Bases of Ideology and System of Justification", in H. Thorisdottir, J. Jost, A. Kay (eds.) Social and Psychological Bases of Ideology and System Justification, Oxford: Oxford University Press.

Torcal, Mariano (2016) "Political trust in Western and Southern Europe", in S. ZMERLI and T. VAN DER MEER (eds.) Handbook on Political Trust, Cheltenham: Edward Elgar Publishing.

Torcal, Mariano (2014) "The Decline of Political Trust in Spain and Portugal: Economic Performance or Political Responsiveness?", American Behavioral Scientist, 58 (12), 1542-1567. https://doi.org/10.1177/0002764214534662

Weßels, Bernhard (2007) "Political representation and democracy", in R. DALTON and H. DIETER (eds.) The Oxford Handbook of Political Behavior, Oxford: Oxford University Press. 
